\title{
FEAR OF CONTRACTING COVID-19: INFLUENCE OF INFORMATION SOURCES AND MESSAGE CONTENT ON FEAR- AROUSAL AMONG BODA BODA RIDERS IN NAIROBI COUNTY, KENYA
}

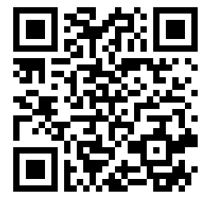

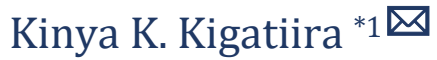 \\ ${ }^{* 1}$ Department of Journalism and Communication, Faculty of Media and Communication, \\ Multimedia University of Kenya
}

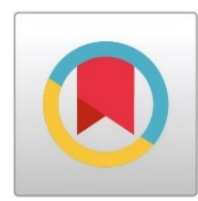

DOI: https://doi.org/10.29121/granthaalayah.v8.i8.2020.998

Article Type: Research Article

Article Citation: Kinya K. Kigatiira. (2020). FEAR OF CONTRACTING COVID-19: INFLUENCE OF

INFORMATION SOURCES AND MESSAGE CONTENT ON FEARAROUSAL AMONG BODA BODA RIDERS IN NAIROBI COUNTY, KENYA. International Journal of Research -GRANTHAALAYAH, 8(8), 190-199.

https://doi.org/10.29121/granthaa layah.v8.i8.2020.998

Received Date: 05 August 2020

Accepted Date: 28 August 2020

Keywords:

Information Sources

Message Content

Fear-Arousal

COVID-19

Boda Boda Riders

\section{ABSTRACT}

This study examined the influence of information sources and message content on COVID-19 in fear-arousal among boda boda riders in Nairobi County, Kenya. Little if any research has explored the influence of information sources and message content on fear arousal among boda boda riders, hence a gap that needed to be filled. The study was guided by the agenda-setting and framing theories. Case study research design was utilized. Convenience sampling was used to identify the study respondents. Telephone interviews were used to collect data. Qualitative data obtained through interviews was manually transcribed, coded and analyzed for themes. Findings revealed that television and radio were the main sources of information on the COVID-19 pandemic. Messages from information sources contained frightening phrases such as, "Coronavirus kills," "COVID19 is a deadly disease," "Coronavirus is a dangerous disease," and "The virus is highly contagious." Information sources and message content on COVID-19, therefore, aroused high levels of fear among boda boda riders. The study recommended that journalists should exercise caution and discretion, when covering news stories on infectious disease outbreaks. Moreover, news on contagions should be reported ethically and objectively. This will prevent the arousal of too much fear, which may result to mental breakdown among the receivers of the messages.

\section{INTRODUCTION}

In the current 24-hours news and digital media environment, people constantly receive information from many sources which are widely available. Information sources can be individuals, groups, institutions or organizations. According to Walter et al. (2012) the main sources of information on pandemics are the internet and mass media, such as, television, radio, magazines and newspapers. Oh et al. (2015) assert that when people do not have firsthand experience or knowledge on an infectious disease, they are more likely rely on mass media to learn about the disease outbreak. Interpersonal relationships made through social ties such as friends, family, community organizations or those with healthcare providers may also be sources of health information (Nellis \& Savage, 2012). According to Miller (1973) messages delivered through the mass media often stimulate interpersonal discussions about a health issue.

(C) 2020 The Author(s). This is an open access article distributed under the terms of the Creative Commons Attribution License, which permits unrestricted use, distribution, and reproduction in any medium, provided the original author and source are credited. 
Fear of Contracting Covid-19: Influence of Information Sources and Message Content on Fear- Arousal Among Boda Boda Riders in Nairobi County, Kenya

In recent years, the media as an information source, has shaped the coverage of disease outbreaks by heightening fear while serving as a useful tool for encouraging precautions and prevention (Moukaddam, 2019). The use of fear appeals in the form of threatening health messages, is a commonly used strategy for health promotion, disease prevention and adoption of behaviour within a population (Brown \& Whiting, 2014; Simpson, 2017; Sweene \& Stephens, 2013). This tactic involves using images or messages to elicit negative emotions such as fear and anxiety, in the expectation that the target audience will be motivated to adopt the recommended health behaviours (Brown \& Whiting, 2014).

The coronavirus disease 2019 (COVID-19), which was first discovered in December 2019 in Wuhan, the capital of Hubei Province in Central China, has aroused fear among people all over the world. The virus is highly contagious, which means it can be spread, directly or indirectly, from one person to another. Densely populated communities or cities enhance its quick spread (WHO, 2020). The virus is spread through respiratory droplets transmitted into the air from coughing or sneezing, which people nearby can take in through their nose, mouth or eyes. It can also be transmitted when human beings touch surfaces that are contaminated with the virus and further, with their unclean hands, touch their eyes, nose and mouth (Africa Center for Disease Control and Prevention, 2020).

COVID-19 is a new and an unknown disease that has neither cure nor vaccine. "Moreover, millions of people have been infected and hundreds of thousands have lost their lives to the virus, worldwide" (Kigatiira, 2020). As of $21^{\text {st }}$ July 2020, there were 15,098,721 coronavirus cases, worldwide. Out of the positive cases, 9,116,242 had recovered and 619,593 had died. In Africa, there were 736,587 confirmed cases, 389,314 recoveries and 15,424 deaths (WHO, 2020). Kenya had a total of 14,168 coronavirus cases, 6,258 recoveries and 250 deaths. Out of the 47 counties in Kenya, Nairobi County had the highest number of COVID-19 positive cases, 8,275, out of the 14,168 people who had tested positive, countrywide (Ministry of Health, 2020).

Over the years, research on information sources and message content in health communication has increasingly gained impetus, worldwide. However, there is a dearth of knowledge in this area, as little if any research has investigated the influence of information sources and message content on fear arousal among commercial motorcycle operators, commonly known as boda boda riders. Specifically, there is no study that has investigated the influence of information sources and message content on COVID-19 in arousing fear among boda boda riders. Thus, the purpose of this study was to examine the influence of information sources and message content on COVID-19 in arousing fear among boda boda riders in Nairobi County, Kenya.

\section{THEORETICAL FRAMEWORK}

\subsection{AGENDA- SETTING THEORY}

The agenda- setting theory was developed in 1972 by two professors, Maxwell McCombs and Donald Shaw. The theory looks at how the media news coverage determines which issues become the focus of public attention (Alvernia University, 2018). When reporters give particular news prominence and attention, by giving the stories extensive media coverage, the audience automatically perceive it as such (Alvernia University, 2018; WahlJorgensen, 2020). The agenda-setting theory is based on two major assumptions. First, the media filters what is happening by focusing on a few issues, making them more prominent, while ignoring other stories (Winters et al., 2020). Secondly, the more attention an issue is given by the media, the more likely the public will consider it to be important (Alvernia University, 2018). Therefore, the agenda-setting theory doesn't necessarily tell people what to think but what issues they should think about (Wahl-Jorgensen, 2020). Although the agenda-setting theory doesn't particularly examine how interpersonal and social media information sources make news stories the focus of public attention, the theory was critical in determining how the mass media made the COVID-19 pandemic the focus of public attention, thus arousing fear.

\subsection{FRAMING THEORY}

The concept of framing was first posited by Anthropologist Gregory Bateson, in 1972. Framing is the practice of thinking about news items and story content within familiar context. The theory explains that the media create the frame by introducing news items with predefined and narrow contextualization. "Frames can be designed to enhance 
understanding or are used as cognitive shortcuts to link stories to the bigger picture" (Arowolo, 2017). The framing theory suggests that the way news stories are presented to the audience (called "the frame"), determine how people understand and remember a news story, as well as how they evaluate and choose to respond to it (Entman, 1993; Goffman, 1974). Framing is also referred to as second-level agenda-setting because it focuses on the way the media draws the public's eye to specific topics- setting agenda, and then takes a step further to create a frame, through which the audience will comprehend the information (Arowolo, 2017). In this study, the framing theory was used in identifying the manner in which the mass media present news stories on the COVID-19 pandemic and subsequently aroused fear among boda boda riders in Nairobi County.

\section{LITERATURE REVIEW}

\subsection{INFORMATION SOURCES ON INFECTIOUS DISEASE OUTBREAKS}

When there is an outbreak of an infectious disease, people constantly receive information from multiple sources which are widely available. According to Walter et al. (2012) the main sources of information on pandemics include mass media, such as, television, radio, magazines and newspapers and the internet. For example, at the onset of the SARS outbreak, the global media reported dramatic stories from Asia in print media, television and the internet (Person et al., 2004). Oh, et al. (2015) asserts that when people do not have firsthand experience or knowledge on an infectious disease, they are more likely to rely on mass media to learn about the disease outbreak. The traditional mass media, play an enormously influential role in public responses to health issues (Leask et al., 2010). According to Gunther (1998) and McCombs and Shaw (1972) the mass media has an unparalleled reach as a communication mechanism and substitutional power in setting agendas on what people should be concerned about and take action on. In addition, mass media frames issues by influencing how people should think about the information given. However, mass media can be expensive and doesn't necessarily target specific populations (Wakefield et al., 2010).

Besides the traditional mass media, the internet is also a popular and important source of health information because it is available, affordable and versatile. In addition, it offers high quality, huge volume, current and relevant information (Lagoe \& Atkin, 2015). According to Rains (2007) studies have found that many of those who use the traditional media and healthcare professionals as sources of health information, also turn to the internet as an alternative source of health information, in order to gain a different perspective from what they have read or heard. Social media and websites are internet platforms that more people are turning to as sources of health information. Social media are a potentially useful tool for effective dissemination of information to the public on emerging infectious disease (EID) outbreaks updates and important medical information (Tang et al., 2018). For instance, social media has been instrumental in informing the public about recent EID outbreaks such as the 2014 Ebola outbreak and the 2009 A(H1N1) Influenza pandemic (Biswas, 2013). Moreover, government agencies such as the Center for Disease Control and Prevention (CDC), used social media to inform the public about the Zika and Ebola outbreaks (Chan et al., 2018; Lazard et al., 2015). Social media, according to Jang and Baek (2019), functions as a firsthand information source from which the public obtain disease-related information which they share with their family, friends and neighbours in real time. Further, when traditional media does not provide relevant and timely information to the public, social media serves as a major immediate information source (Jang \& Baek, 2019; Yoo, Chio \& Park, 2016).

Official government websites are associated with high knowledge of diseases. However, a study by Koralek et al. (2016) revealed that the websites, as sources of information, have low popularity among college students. Previous research indicates that distrust in health information from government agencies may contribute to its low popularity. For example, two United States federal agencies charged with protecting publics' health, the Food and Drug Administration (FDA) and CDC, released conflicting statements and recommendations to the public about the use and efficacy of Tamiflu, a flu medication. The contrasting messages diminished the public's trust of the two agencies, presumed to present a united front on health issues (Mandrola, 2015). According to Koralek et al. (2016) distrust can affect audiences' receptivity and responses to public health information.

Interpersonal communication sources of information, such as healthcare providers, family and friends, are consistently ranked as reliable sources of health information. However, the sources have more limited reach compared to social and mass media and may be difficult to quantify or standardize (Leisen \& Hyman, 2001; Sharma \& Romas, 2016). According to Carlson and Goss (2016), people who live in rural areas and are in dire situations, rely 
Fear of Contracting Covid-19: Influence of Information Sources and Message Content on Fear- Arousal Among Boda Boda Riders in Nairobi County, Kenya

on doctors as a source of health information because they have less internet access, lower device use and less participation in online activities compared to those living in urban areas. Clinicians are also a trusted resource for information on serous health concerns and support (Fox \& Duggan, 2013).

Community meetings are common both in the rural areas and informal settlements in urban areas. They are used for sharing health information and gathering community opinions on health issues. The gatherings have been used with success to understand community perspectives on health programs (Naanyu et al., 2013). Families are also important in health promotion, not only within the family itself, but also in the larger society (Wong \& Sam, 2010). Through observation and interaction, individuals in a family learn and sustain healthy or unhealthy behaviours practiced by their relatives (Huidobro \& Mendenhall, 2015).

\subsection{MESSAGE CONTENT}

Public health initiatives use fear appeals in the form of threatening health messages, as a strategy for health promotion, disease prevention and adoption of behaviour within a population (Brown \& Whiting, 2014; Simpson, 2017; Sweene \& Stephens, 2013). This tactic involves using images or messages to elicit negative emotions such as fear and anxiety, in the expectation that the target audience will be motivated to adopt the recommended health behaviours (Brown \& Whiting, 2014). The media has also shaped the coverage of disease outbreaks by heightening fear while serving as a useful tool for encouraging precautions and prevention (Moukaddam, 2019). For example, at the onset of the SARS outbreak, fear of the infectious disease was heightened by headlines from the English-language press (Person et al., 2004). The British Broadcasting Corporation in London, wrote, "Concern is mounting over the continuing spread of the deadly SARS virus. Some experts say it could have a similar impact to the 1918 flu epidemic that killed 50 million people or the current world HIV crisis" (British Broadcast Corporation, 2003). On the same note, the Cable News Network from Beijing, stated, "China has threatened to execute or jail for life anyone who deliberately spreads the killer virus" (Cable News Network, 2003).

During the 2013-2016 West Africa Ebola virus disease (EVD) outbreak, photographs of the virus most recognized mammalian "reservoir" the fruit bat, aroused fear by showing the creature hanging, inverted with its wings spread and fangs menacing. In addition, frightening visuals depicting the end stage of Ebola virus disease, scary messages such as "Ebola Kills," and pessimistic pronouncements that there was no cure, aroused public fear (Shultz et al., 2016). Britain's first national mass media campaign in response to the emergence of HIV/AIDS in the 1980 's, used the images of tombstones and icebergs to emphasize the severe and potentially fatal threat of the disease. Moreover, the message that "AIDS Kills" aroused fear among those who engaged with the message (Bourne, 2010).

Stories on the ongoing outbreak of the novel coronavirus disease 2019 (COVID-19) have received extensive media attention and coverage, and have hence aroused fear among people all over the world (Judd, 2020; WahjJorgense, 2020). Professor Wahl-Jorgensen of Cardiff University, asserted that since emotions are contagious and spread across populations, "the fear of coronavirus is far more contagious than the disease itself." "Fear of the new contagion has, paradoxically, become a global infection" (Judd, 2020). Major English-language newspapers around the world mention "fear" or related words, including, "afraid." In addition, such articles use frightening-language (fear-inducing language), for example, the use of phrases such as, "Killer virus," "Deadly disease" to refer to the coronavirus (Wahj-Jorgense, 2020).

\subsection{FEAR OF CONTRACTING INFECTIOUS DISEASES}

According to Morens et al., (2008) emerging infectious diseases remain among the key challenges to human survival. The transmissible, imminent and invisible nature of the diseases have a tendency of arousing fear (Pappas et al., 2009). Further, the evolving nature and inherent scientific uncertainties of the diseases is associated with considerable fear in the general public or in specific communities, particularly when illness and deaths are substantial (Person et al, 2004). For example, the outbreak of severe acute respiratory syndrome (SARS) which spontaneously appeared in the southern province of Guangdong, People's Republic of China, in November 2002 (Centre for Disease Control \& Prevention, 2003; Rosling \& Rosling, 2003) aroused fear and anxiety because the disease had an unknown cause and possible fatal outcome (Das, 2001). Fear is a negative emotional reaction that is 
usually accompanied by heightened physiological arousal to a perceived threat on an individual's well-being (Gore et al., 1998). However, fear arousal as a reaction in response to infectious diseases, is considered normal and potentially adaptive or protective (McEwen, 2007). During the 2013-2016 EVD outbreak, fear was understandable, reality-based and almost universal (Van Bortel et al., 2016).

\section{METHODOLOGY}

\subsection{STUDY DESIGN}

Case study research design which focused only on boda boda riders was used. The design was appropriate because the study sought to investigate the influence of information sources and message content on COVID-19 in fear arousal among boda boda riders in Nairobi County, Kenya.

\subsection{POPULATION OF THE STUDY}

The population of the study comprised of all the boda boda riders operating in Nairobi County. It is important to note that there were no official statistics on the exact number of boda boda riders operating in Nairobi County. According to the Independent Electoral and Boundaries Commission (2013), Nairobi County is divided into 17 constituencies namely: Westlands, Dagoretti North, Dagoretti South, Langata, Kibra, Kasarani, Roysambu, Starehe, Ruaraka, Mathare, Embakasi North, Embakasi East, Embakasi South, Embakasi West, Embakasi Central, Makadara and Kamukunji. All constituencies in Nairobi County were included, such that the study findings formed a representative section of the entire county.

\subsection{SAMPLE AND SAMPLING TECHNIQUE}

This study used qualitative sampling technique. A qualitative sample size is best determined by the time allocation, resources available, the objectives of the study (Patton, 1990) and data saturation (Fusch \& Ness, 2015). Different scholars give varying numbers for participants to be interviewed in a qualitative study. For example, Guest et al. (2006) found that 12 interviews conducted from a homogeneous sample is enough to reach data saturation. Similarly, Kuzel (1992) recommended 6-12 interviews for a homogeneous sample. However, Green and Thorogood (2004) noted that most qualitative researchers experienced data saturation after interviewing approximately 20 participants belonging to one analytical relevant category. Therefore, based on Green and Thorogood (2004), Guest et al. (2006) and Kuzel (1992) recommendations, this study interviewed one boda boda rider from each of the 17 constituencies in Nairobi County, totaling to a sample size of 17 respondents. Convenience sampling was used in identifying boda boda riders who were available and willing to participate in the study. The respondents were identified by the researcher's friends, colleagues and relatives who reside in different constituencies in Nairobi County.

\subsection{DATA COLLECTION}

The researcher used qualitative data collection methods. The main data collection tool was telephone interviews with boda boda riders. Advantages of telephone interviews include ability to reach respondents who are dispersed in a large geographical area, enhanced interviewer safety, decreased cost and travel (Aday 1996; Bernard, 2006). In this study, telephone interviews were the most appropriate data collection tools because they enabled the researcher to work from home and have physical distance with the respondents. Abiding by these precautionary measures prevented the researcher and respondents from contracting and spreading the coronavirus disease during data collection.

\subsection{DATA ANALYSIS}

Qualitative data obtained through telephone interviews was coded and analyzed for themes. Data were transcribed manually. That is, the researcher listened to each of the recorded interviews and recorded them on 
paper. During the transcription process, the researcher took note of how the respondents expressed their feelings during the interview sessions. After transcription, the researcher read and made sense out of the collected data. The data for each question was put together, coded and categorized into relevant themes and sub-themes according to the objectives of the study. For easy identification and interpretation of themes, the researcher marked key phrases with different colored pens. Consistencies and differences in the data were identified by making systematic comparisons across categories of data. Finally, the researcher made possible and plausible explanations of the findings.

\section{FINDINGS AND DISCUSSION}

\subsection{DEMOGRAPHIC INFORMATION}

All the respondents in the study were male. This implies that the boda boda business sector is dominated by males. In terms of the age of the boda boda riders, most of them were youths because majority ranged between 30 39 years while a minority were between $40-49$ years and one was 24 years. Most of the riders had an experience of between one to ten years in the boda boda business, while a minority had 11-20 years, experience. This implied that the respondents were in the boda boda business long enough to be able to provide relevant information for the study. Majority of the respondents were married while a minority were single. Most boda boda riders had attained primary school education followed by those with secondary school education. Further, one rider was a university graduate and another had no formal education. The low levels of education that most boda boda riders had attained, reduces their chances of getting jobs in the formal sector. Therefore, the operators rely on the boda boda business as a source of income to be able to take care of their family financial needs.

\subsection{INFORMATION SOURCES ON COVID-19}

All the respondents in this study asserted that the television and radio were the main sources of information on the coronavirus disease. Other sources of information on the disease were fellow boda boda riders, social media, that is Facebook and WhatsApp, public awareness campaigns, short message service (SMS) from Safaricom communications company and newspapers, respectively. For instance, one boda boda operator said, "I got to know about the coronavirus disease while watching the news in the television one evening. In addition, we discuss news stories reported in the mass media amongst us boda boda riders."

Another respondent said:

I first heard about the disease when it was announced by the Ministry of Health via the radio. I later received an SMS from Safaricom, informing me of the pandemic. The Kenya Medical Training College (KMTC) also created awareness of the coronavirus disease through a road show.

Findings of the study revealed that television and radio were the main sources of information. This finding is in agreement with Walter et al. (2012) who asserted that the mass media are key sources of information on pandemics. Findings further revealed that boda boda riders who received information about the coronavirus disease from the mass media, discussed the news stories amongst themselves. The interpersonal discussions, subsequently, made the riders key information sources to other operators who had not heard about the virus. This finding is in tandem with Miller (1973) who noted that messages delivered through the mass media often stimulate interpersonal discussions about a health issue.

\subsection{MESSAGE CONTENT ON COVID-19}

Study respondents reported that messages from information sources contained frightening phrases such as, "Coronavirus kills," "COVID-19 is a deadly disease," "Coronavirus is a dangerous disease," and "The virus is highly contagious." "I have heard that coronavirus kills," said a boda boda rider. Another respondent said, "I have heard that the disease is highly contagious and is spread from person to person when there is body contact like a hand shake." Moreover, the riders were in agreement that the messages on the coronavirus disease did not contain any images 
that aroused the fear of contracting the disease. Some of the boda boda operators said, "We have not yet been shown pictures of people who have contracted the disease. We would like to see how they look like when they are ill."

The study revealed that messages on COVID-19 contained phrases that aroused fear. This finding is in agreement with that of Wahj-Jorgense (2020) who found that articles on the coronavirus disease use fear-inducing phrases, such as, "Killer virus," and "Deadly disease" to refer to the virus. Moreover, there were no images that aroused the fear of contracting the virus. Brown and Whiting (2014) asserted that images or messages are used to elicit negative emotions such as fear and anxiety.

\subsection{Fear of Contracting COVID-19}

All the respondents said that they feared contracting the coronavirus disease because the disease has neither cure nor vaccine and that one can either get well or lose their life. In addition, the boda boda riders asserted that they experienced high levels of fear. One respondent said, "Nobody wants to die. Contracting the coronavirus disease, according to me, is like a death sentence."

Findings of the study revealed that boda boda riders feared contracting COVID-19. This finding is in tandem with Pappas et al. (2009) who asserted that the transmissible, imminent and invisible nature of emerging infectious diseases have a tendency to arouse fear. Moreover, fear arousal as a reaction in response to infectious diseases, is considered normal and potentially adaptive or protective (McEwen, 2007).

\section{CONCLUSION}

Information sources and message content aroused the fear of contracting COVID-19 among boda boda riders in Nairobi County, Kenya. Television and radio were the main sources of information on the coronavirus disease. Other sources of information on the disease were fellow boda boda riders, social media (Facebook and WhatsApp), public awareness campaigns, short message service (SMS) from Safaricom communications company and newspapers, respectively. Whereas messages on COVID-19 used frightening language, there were no images that aroused the fear of contracting the virus.

\section{RECOMMENDATION}

Journalists should exercise caution and discretion, considering that mass media are a main source of information on pandemics. News stories covering infectious disease outbreaks should be reported ethically and objectively. This will prevent the arousal of too much fear, which may result to mental breakdown among the receivers of the messages.

\section{SOURCES OF FUNDING}

This research received no specific grant from any funding agency in the public, commercial, or not-for-profit sectors.

\section{CONFLICT OF INTEREST}

The author have declared that no competing interests exist.

\section{ACKNOWLEDGMENT}

None.

\section{REFERENCES}

[1] Aday, L. A. (1996). Designing and conducting health surveys. Jossey-Bass. 
Fear of Contracting Covid-19: Influence of Information Sources and Message Content on Fear- Arousal Among Boda Boda Riders in Nairobi County, Kenya

[2] Africa Center for Disease Control and Prevention. (2020). Coronavirus Disease (COVID-19). https://africacdc.org/covid-19/

[3] Alvernia University (2018, February 19). The agenda-setting theory in mass communication. https://online.alvernia.edu/articles/agenda-setting-theory/

[4] Arowolo, S. O. (2017, March). Understanding framing theory. Working Paper. ResearchGate.net. https://www.researchgate.net/publication/317841096

[5] Bernard, H. R. (2006). Research methods in anthropology: Qualitative and quantitative approaches. Rowman \& Littlefield Publishers, Inc.

[6] Biswas, M. (2013). Health organizations' use of social media tools during a pandemic situation: An H1N1 context. Journal of New Communications Research, 5(1), 46-81.

[7] Bourne, A. (2010). The role of fear in HIV prevention. Make it count: Briefing sheet 1. https://www.poz.com/pdfs/sos_sigma_roll_fear_prevention_2010.pdf

[8] British Broadcast Corporation. (2003, April 24). SARS: Is a global panic justified? BBC News UK Edition.

[9] Brown, S. L., \& Whiting, D. (2014). The ethics of distress: Towards a framework for determining the ethical acceptability of distressing health promotion advertising. International Journal of Psychology, 49(2), 89-97. doi: 10-1002/ijop.12002

[10] Cable News Network. (2003, May 16). Death of SARS spreaders: China.

[11] Carlson, E. \& Goss, J. (2016, August 10). The state of the urban/rural digital divide. National Telecommunications and Information Administration.

[12] Centre for Disease Control \& Prevention. (2003). Update: Severe acute respiratory syndrome- Worldwide and United States, 2003. MMWR Morbidity \& Mortality Weekly Report, 52(8), 664.

[13] Chan, M. S., Winneg, K., Hawkins, L., Farhadloo, M., Jamieson, K. H., \& Albarracin, D. (2018). Legacy and social media respectively influence risk perceptions and protective behaviours during emerging health threats: A multi-wave analysis of communications on Zika virus cases. Social Science \& Medicine, 212, 50-59.

[14] Das, V. (2001). Stigma, contagion, defect: Issues in the anthropology of public health. Sigma and Global Health: Developing a research agenda, September 5-7, Bethesda, Maryland.

[15] Entman, R. (1993). Framing: Toward clarification of a fractured paradigm. Journal of Communication, 43(4), 54.

[16] Fox, S., \& Duggan, M. (2013, January 15). Health online 2013. Pew Research Center. https://www.pewresearch.org/internet/2013/01/15/health-online-2013/

[17] Fusch, P. I., \& Ness, L. R. (2015). Are we there yet? Data saturation in qualitative research. The Qualitative Report, 20(9), 1408-1416. https://cpb-us-east-1juc1ugur1qwqqqo4.stackpathdns.com/sites.nova.edu/dist/a/4/files/2015/09/fusch1.pdf

[18] Goffman, E. (1974). Frame analysis: An essay on the organization of experience. Harvard University Press.

[19] Gore, P., Madhavan, S., Curry, D., \& McClurg, G. (1998). Persuasive messages. Marketing Health Services, 18(4), 32-43.

[20] Green, J., \& Thorogood, N. (2004). Qualitative methods for health research. Sage Publications Ltd.

[21] Guest, G., Bunce, A., \& Johnson, L. (2006). How many interviews are enough ? An experiment with data saturation and variability. Field Methods, 18(1), 59-82. https://doi.org/10.1177/1525822X05279903

[22] Gunther, A. C. (1998). The persuasive press influence: Effects of mass media on perceived public opinion. Communication Research, 25(5), 486-504.

[23] Huidobro, D., \& Mendenhall, T. (2015). Family oriented care: Opportunities for health promotion and disease prevention. Journal for Family Medicine and Disease Prevention, 1(2), 1-6.

[24] Independent Electoral and Boundaries Commission (IEBC) (2013). 4Th March 2013 general election: Election data. https://www.iebc.or.ke/uploads/resources/EIqEo3LuiB.pdf

[25] Jang, K., \& Baek, Y. M. (2019). When information from public health officials is untrustworthy: The use of online news, interpersonal networks and social media during the MERS outbreak in South Korea. Health Communication, 34(9), 991-998.

[26] Judd, B. (2020, March 6). Our fear of coronavirus could be 'far more contagious than the disease itself.' https://www.abc.net.au/news/2020-03-07/our-fear-of-coronavirus-could-be-more-contagious-thandisease/12025490 
[27] Kigatiira, K. K. (2020). Efficacy of fear appeals on adoption of COVID-19 preventive measures: A case of boda boda riders in Nairobi County, Kenya. International Journal of Research-GRANTHAALAYAH, 8(6), 219-228.

[28] Koralek, T., Runnerstrom, M. G., Brown, B. J., Uchegbu, C., \& Basta, T. B. (2016). Lesson from Ebola: Sources of outbreak information and the associated impact on UC Irvine and Ohio university college students. PLOS currents Outbreaks, 8. https://www.ncbi.nlm.nih.gov/pmc/articles/PMC5016197/

[29] Kuzel, A. J. (1992). Sampling is qualitative inquiry. In B. F. Crabtree \& W. L. Miller (Eds.), Research methods for primary care, Vol. 3. Doing qualitative research (p. 31-44). Sage Publication, Inc.

[30] Lagoe C., \& Atkin, D. (2015). Health anxiety in the digital age: An exploration of psychological determinants of online information seeking. Computers in Human Behaviour, 52, 484-491.

[31] Lazard, A. J., Scheinfeld, E., Bernhardt, J. M., Wilcox, G. B., \& Suran, M. (2015). Detecting themes of public concern: A text mining analysis of the centers of disease control and prevention's Ebola live Twitter chat. American Journal of Infection Control, 43(10), 1109-1111.

[32] Leask, J., Hooker, C., \& King, C. (2010). Media coverage of health issues and how to work more effectively with journalists: A qualitative study. BMC Public Health, 10(1), 535.

[33] Leisen, B., \& Hyman, M. R. (2001). An improved scale for assessing patients trust in their physician. Health Marketing Quarterly, 19(1), 23-42.

[34] Mandrola, J. (2015, February 13). Public trust, the CDC and Tumiflu. https://www.drjohnm.org/2015/02/public-trust-the-cdc-and-tamiflu/

[35] McCombs, M., \& Shaw, D. (1972). The agenda-setting function of mass media. Public Opinion Quarterly, 36(2), 176-187.

[36] McEwen, B. S. (2007). Physiology and neurobiology of stress and adaptation: Central role of the brain. Physiological Reviews, 87(3), 873-904.

[37] Miller, M. H. (1973). Seeking advice for cancer symptoms. American Journal of Public Health, 63(11), $955-961$.

[38] Ministry of Health. (2020). COVID-19 updates. https://www.health.go.ke/

[39] Morens, D. M., Folkers G. K., \& Fauci, A. S. (2008). Emerging infections: a perpetual challenge. Lancet Infectious Diseases, 8(11), 710-719.

[40] Moukaddam, N. (2019). Fear, outbreaks and pandemics: Lessons learned. Psychiatric Times, 36. https://www.psychiatrictimes.com/view/fears-outbreaks-and-pandemics-lessons-learned

[41] Naanyu, V., Baliddawa, J., Peca, E., Karfakis, L., Nyagoha, N., \& Koech, B. (2013). An examination of postpartum family planning in Western Kenya: "I want to use contraception but I have not been told how to do so." African Journal of Reproductive Health, 17(3), 44-53.

[42] Nellis, A. M., \& Savage, J. (2012). Does watching the news affect fear of terrorism? The importance of media exposure on terrorism fear. Crime \& Delinquency, 58(5), 748-768.

[43] Oh, S. H., Paek, H. J., \& Hove, T. (2015). Cognitive and emotional dimensions of perceived risk characteristics, genre-specific media effects and risk perceptions: The case of H1N1 Influenza in South Korea. Asian Journal of Communication, 25(1), 14-32.

[44] Pappas, G., Kiriaze, I. J., Giannakis, P., \& Falagas, M. E. (2009). Psychosocial consequences of infectious diseases. Clinical Microbiology and Infection, 15(8), 743-747.

[45] Patton, M. (1990). Qualitative evaluation and research methods. SAGE Publications, inc.।

[46] Person, B., Sy, F., Holton, K., Govert, B., \& Liang, A. (2004). Fear and stigma: The epidemic with the SARS outbreak. Emerging Infectious Diseases, 10(2), 358.

[47] Rains, S. A. (2007). Perceptions of traditional information sources and the use of the world wide web to seek health information: Findings from the health information national trends survey. Journal of Health Communication, 12(7), 667-680.

[48] Rosling, L., \& Rosling, M. (2003). Pneumonia causes panic in Guangdong province. BMJ, 326-416.

[49] Sharma, M., \& Romas, J. (2016). Theoretical foundations of health education and health promotion. Jones \& Bartlett Publishers.

[50] Shultz, J. M., Cooper, J. L., Baingama, F., Oquendo, M. A., Espinel, Z., Althouse, B. M., Marcelin, L. H., Towers, S., Espinola, M., McCoy, C. B., Mazurik, L., Wainberg, M. L., Neria, Y., \& Rechkemmer, A. (2016). The role of fear related behaviours in the 2013-2016 West Africa Ebola virus disease outbreak. Current Psychiatry Reports, 18(11), 104.

[51] Simpson, J. K. (2017). Appeal to fear in health care: appropriate or inappropriate? Chiropractic \& Manual Therapies, (25)1, 27. https://www.researchgate.net/publication/319940664 
[52] Sweene, K., \& Stephens, S. (2013). The use of fear appeals to communicate public health messages. Irish Business Journal, 8(1), 87-96. https://www.researchgate.net/publication/331319860

[53] Tang, L., Bie, B., Park, S. \& Zhi, D. (2018). Social media and outbreaks of emerging infectious diseases: A systematic review of literature. American Journal of Infection Control, 46(9), 962-972.

[54] Van Bortel, T., Basnayake, A., Wurie, F., Jambai, M., Koroma, A. S., Muana, A. T., Hann, K., Eaton, J., Martin, S., \& Nellums, L. B. (2016). Psychosocial effects of an Ebola outbreak at individual, community and international levels. Bulletin in the World Health Organ, 94(3), 210-214.

[55] Wahj-Jorgense, K. (2020, February 14). Coronavirus: How media coverage of epidemics often stokes fear and panic. The Conversation. https://theconversation.com/coronavirus-how-media-coverage-of-epidemicsoften-stokes-fear-and-panic-131844

[56] Wakefield, M. A., Loken, B., \& Harnik, R. C. (2010). Use of mass media campaigns to change health behaviour. Lancet, 376(9748), 1261-1271.

[57] Walter, D., Bohmer, M., Reiter, S., Krause, G., \& Wichmann, O. (2012). Risk perception and information-seeking behaviour during 2009/10 Influenza A(H1N1) Pdm09 pandemic in Germany. Eurosurveillance, 17(13), 20131.

[58] Winters, M., Nordenstedt, H., \& Alvesson, H. M. (2020). Reporting in a health emergency: The role of Sierra Leonean journalists during the 2014-2015 Ebola outbreak. PLOS Neglected Tropical Diseases, 14(5). https://journals.plos.org/plosntds/article?id=10.1371/journal.pntd.0008256

[59] Wong, L. P., \& Sam,I. C. (2010). Public sources of information and information needs for pandemic Influenza A(H1N1). Journal of Community Health, 35(6), 676-682. https://link.springer.com/article/10.1007/s10900010-9271-4

[60] World Health Organization (2020, June 4). Coronavirus disease (COVID-19) advice for the public. Retrieved from https://www.who.int/emergencies/diseases/novel-coronavirus-2019/advice-for-public

[61] Yoo, W., Chio, D., \& Park, K. (2016). The effects of SNS communication: How expressing and receiving information predict MERS- prevention behavioural intentions in South Korea. Computers in Human Behaviour, 62,34-43. 